\title{
Arctic Ocean outflow and glacier-ocean interactions modify water over the Wandel Sea shelf (northeastern Greenland)
}

\author{
Igor A. Dmitrenko ${ }^{1}$, Sergey A. Kirillov ${ }^{1}$, Bert Rudels ${ }^{2}$, David G. Babb ${ }^{1}$, Leif Toudal Pedersen ${ }^{3}$, Søren Rysgaard ${ }^{1,4,5}$, \\ Yngve Kristoffersen ${ }^{6,7}$, and David G. Barber ${ }^{1}$ \\ ${ }^{1}$ Centre for Earth Observation Science, University of Manitoba, Winnipeg, Canada \\ ${ }^{2}$ Finnish Meteorological Institute, Helsinki, Finland \\ ${ }^{3}$ Technical University of Denmark, Lyngby, Denmark \\ ${ }^{4}$ Greenland Climate Research Centre, Greenland Institute of Natural Resources, Nuuk, Greenland \\ ${ }^{5}$ Arctic Research Centre, Aarhus University, Aarhus, Denmark \\ ${ }^{6}$ Department of Earth Science, University of Bergen, Bergen, Norway \\ ${ }^{7}$ Nansen Environmental and Remote Sensing Centre, Bergen, Norway \\ Correspondence to: Igor A. Dmitrenko (igor.dmitrenko@umanitoba.ca)
}

Received: 18 April 2017 - Discussion started: 20 April 2017

Revised: 11 September 2017 - Accepted: 2 November 2017 - Published: 11 December 2017

\begin{abstract}
The first-ever conductivity-temperaturedepth (CTD) observations on the Wandel Sea shelf in northeastern Greenland were collected in April-May 2015. They were complemented by CTDs taken along the continental slope during the Norwegian FRAM 2014-2015 drift. The CTD profiles are used to reveal the origin of water masses and interactions with ambient water from the continental slope and the tidewater glacier outlet. The subsurface water is associated with the Pacific water outflow from the Arctic Ocean. The underlying halocline separates the Pacific water from a deeper layer of polar water that has interacted with the warm Atlantic water outflow through the Fram Strait, recorded below $140 \mathrm{~m}$. Over the outer shelf, the halocline shows numerous cold density-compensated intrusions indicating lateral interaction with an ambient polar water mass across the continental slope. At the front of the tidewater glacier outlet, colder and turbid water intrusions were observed at the base of the halocline. On the temperature-salinity plots these stations indicate a mixing line that is different from the ambient water and seems to be conditioned by the ocean-glacier interaction. Our observations of Pacific water are set within the context of upstream observations in the Beaufort Sea and downstream observations from the Northeast Water Polynya, and clearly show the modification of Pacific water during its advection
\end{abstract}

across the Arctic Ocean. Moreover, ambient water over the Wandel Sea slope shows different thermohaline structures indicating the different origin and pathways of the on-shore and off-shore branches of the Arctic Ocean outflow through the western Fram Strait.

\section{Introduction}

One of the most significant global issues over the last decade has been the vast change in the Arctic region. The Arctic Science Partnership (ASP) consortium (http://www.asp-net.org) was established to understand connections and processes linking climate, the cryosphere, oceans and ecosystems. Under the framework of ASP, an extensive oceanographic field campaign took place during April and May 2015 from the landfast sea ice that covers the shelf of the Wandel Sea.

The field campaign was based out of the new Villum Research Station located at the Danish military outpost Station Nord at $81^{\circ} 36^{\prime} \mathrm{N}, 16^{\circ} 40^{\prime} \mathrm{W}$ on Prinsesse Ingeborg Peninsula in the very northeastern corner of Greenland (Figs. 1 and 2). Northern Greenland is among the most remote wildernesses of the Northern Hemisphere. Station Nord features a very cold polar tundra climate with an average temperature dur- 


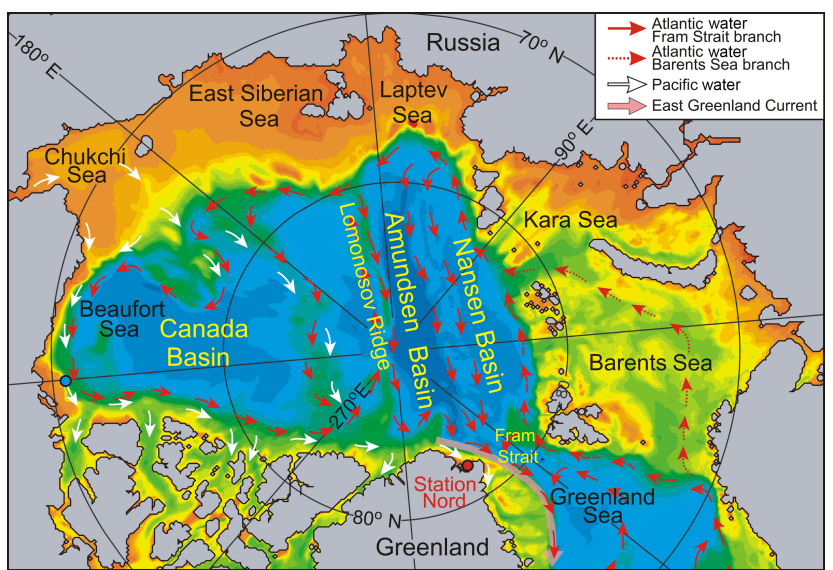

Figure 1. Schematic circulation of the Atlantic Water (AW, red arrows) and Pacific water (PcW, white arrows) in the Arctic Ocean and adjoining Greenland Sea following Rudels et al. (1994), Jones (2001), Rudels (2012) and Woodgate (2013). The dashed and dotted red arrows correspond to the Fram Strait and Barents Sea branches of the AW inflow, respectively. The pink arrow indicates the East Greenland Current. The red dot depicts the position of Station Nord in northeastern Greenland. The blue dot roughly identifies the location where CTD profiles were collected in the Beaufort Sea.

ing winter below $-30^{\circ} \mathrm{C}$ and just a few degrees above the freezing point in the midst of the short summer.

The Wandel Sea is predominantly covered by landfast multiyear sea ice all year around, and only the interior of fjords may become ice-free during late summer (Fig. 2b). The Flade Isblink ice cap is located close to Station Nord (Figs. 2b and 3). It is an isolated ice cap with a surface area of $5000 \mathrm{~km}^{2}$ and maximum thickness of $600 \mathrm{~m}$ that overlies bedrock that is on average $100 \mathrm{~m}$ below sea level (e.g., Palmer et al., 2010; Rinne et al., 2011). In general, the Wandel Sea is rather a glacial inlet than a shelf sea. It is comprised of several fjords open to the continental slope (Fig. 2b). The landfast ice edge in Fig. 2b roughly marks the Wandel Sea continental shelf break located about $35-45 \mathrm{~km}$ from the fjord mouths. The bathymetry of the Wandel Sea shelf and upper continental slope is poorly known. Nørgaard-Pedersen et al. (2008) provided limited information on the bottom topography in the area surrounding Station Nord, specifically the existence of several submarine glacial troughs, with depths of up to $\sim 180 \mathrm{~m}$, that open to the continental slope (Fig. 4a). The bathymetry of the Independence and Denmark fjords is unknown.

Prior to our field program in 2015, there were no oceanographic or in situ sea-ice observations over the Wandel Sea shelf. From very general considerations, the Wandel Sea shelf is expected to be under the influence of the Arctic Ocean outflow through the western Fram Strait (Fig. 1). The upper layer (down to $400 \mathrm{~m}$ ) of this outflow is comprised of low-salinity surface polar water partly including low-salinity water of Pacific origin, and the intermediate water $(>150$

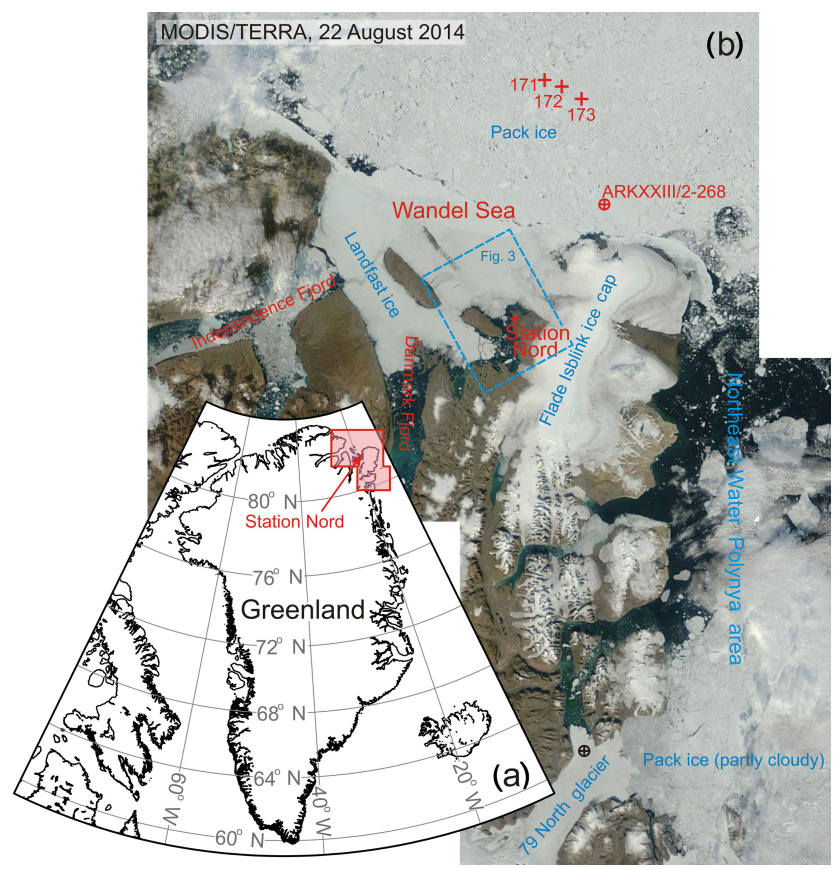

Figure 2. (a) Station Nord (SN) on the Greenland map. The pink shading highlights the Wandel Sea region with the adjoining fjord system, Flade Isblink ice cap (FIIC), the Northeast Water Polynya (NEW) area and the 79 North Glacier outlet enlarged in (b). (b) The MODIS/TERRA satellite image from 22 August 2014 taken over the SN/FIIC/NEW area. Red and black circled crosses indicate the CTD stations occupied over the Wandel Sea outer-shelf during the ARKXXIII/2 expedition in August 2008 and in a rift in the 79 North Glacier in August 2009. Red crosses depict the CTD stations occupied in June-July 2015 over the Wandel Sea continental slope ( $>1000 \mathrm{~m}$ depth) during the Norwegian FRAM 2014-2015 sea-ice drift. The dashed blue rectangle indicates the 2015 study area shown in Fig. 3.

$200 \mathrm{~m}$ ) of Atlantic origin (e.g., Rudels et al., 2002, 2005). The freshwater export through the western Fram Strait is an important component of the Arctic Ocean freshwater budget that links the Arctic Ocean to the global climate system (e.g., de Steur et al., 2009). The coastal branch of the Pacific water flow along the southeast coast of Greenland was reported based on observations (e.g., Bacon et al., 2002; Sutherland and Pickart, 2008; Sutherland et al., 2009) and numerical simulations (Hu and Myers, 2013; Aksenov et al., 2016). However, the pathways of the low-salinity Pacific water along the northeast coast of Greenland are debatable. The Wandel Sea shelf can also be a source of freshwater that originates from summer snow and sea-ice meltwater and from glacier-derived freshwater.

The Atlantic Water outflow through the western Fram Strait with temperatures above $0{ }^{\circ} \mathrm{C}$ in the intermediate water layer $(>150-200 \mathrm{~m}$ ) closes the circulation loop of the Atlantic Water in the Arctic Ocean conditioned by its inflow through the eastern Fram Strait and Barents Sea (e.g., 


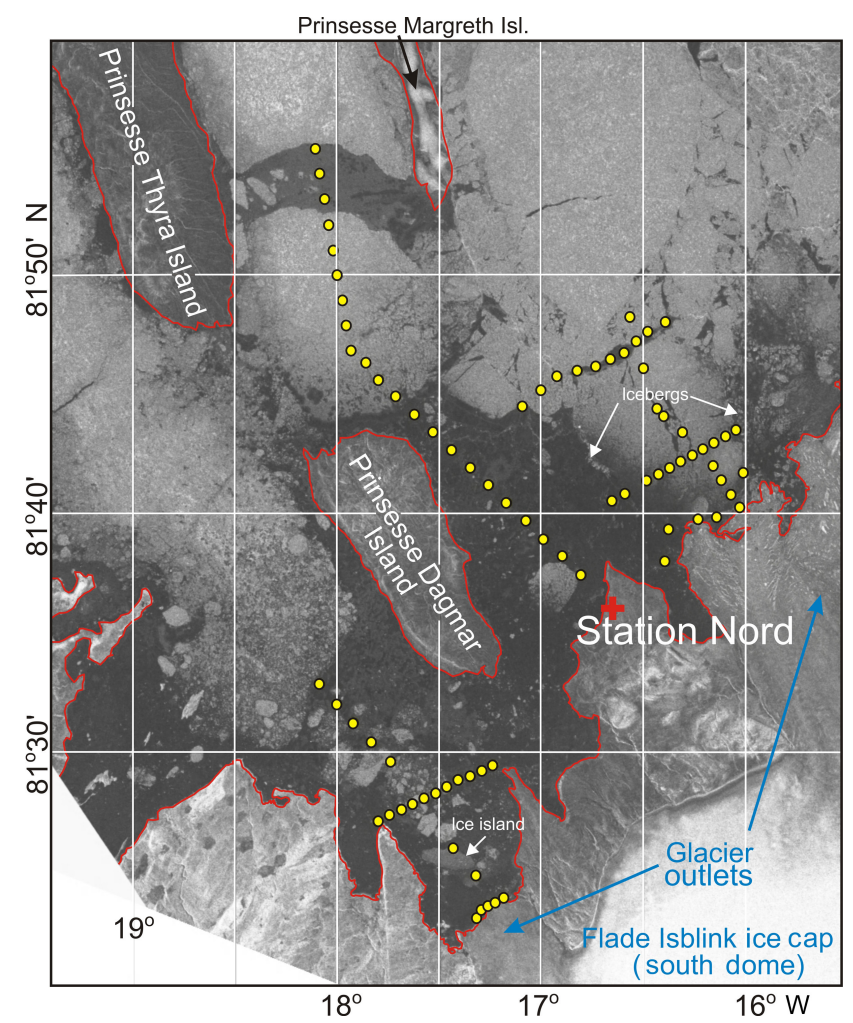

Figure 3. The Sentinel-1 C-SAR image from 2 February 2015 with the CTD stations overlaid. The dark areas along the coast are associated with first-year landfast ice $(<1.8 \mathrm{~m}$ thick). The lighter areas indicate the multiyear landfast ice ( $\sim 2$ to $>4 \mathrm{~m}$ thick). Yellow circles identify stations with CTD measurements. Blue arrows indicate the northern outlet glaciers of the Flade Isblink ice cap.

Rudels et al., 1994; Rudels, 2012) - Fig. 1. The interaction of warm Atlantic Water with tidewater glacier outlets along the southeast coast of Greenland results in ocean-driven glacier melting. This generates additional freshwater flux contributing to the regional freshwater budget (e.g., Straneo et al., 2011, 2012; Sutherland and Straneo, 2012; Inall et al., 2014). For the Wandel Sea shelf, the efficiency of the glacier-ocean interaction is not assessed because of the unknown oceanographic conditions at the glacier-ocean interface.

This paper is focused on analysis of the first-ever conductivity-temperature-depth (CTD) observations on the Wandel Sea shelf collected from the landfast ice in AprilMay 2015 (Fig. 3), to put this region in the context of upstream, downstream and local conditions with a special focus on the Arctic Ocean outflow and ocean-glacier interaction. This data set was complemented by CTDs taken in JuneJuly 2015 over the Wandel Sea continental slope during the Norwegian FRAM 2014-2015 sea-ice drift (Fig. 2b). Our objectives were to investigate the principal features of vertical profiles of salinity and temperature taken over the shelf regions deeper than $100 \mathrm{~m}$ for tracing the water origin and local modifications.
The paper is structured as follows. Section 2 describes observational data on CTD, sea-ice and bottom topography, and justifies the selection of CTD data for our analysis. Section 3 provides a detailed description of the water mass structure over the Wandel Sea shelf and continental slope, methods of clustering the CTD profiles, and the CTD clusters. Section 4.1 discusses oceanographic patterns of the "glacier" CTD cluster with respect to the ocean-glacier interaction. Section 4.2 focuses on the "intrusive" CTD cluster from the Wandel Sea outer shelf. Sections 4.3 and 4.4 discuss local and remote origins of the Wandel Sea water masses. Finally, Sect. 5 concludes the analysis and discusses limitations.

\section{Data and methods}

Between 17 April and 15 May 2015, 86 CTD profiles (labeled SN15-XX; XX is the station number) were collected from the landfast sea ice (1.0 to $3.5 \mathrm{~m}$ thick) on the Wandel Sea shelf in northeastern Greenland (Figs. 3 and 4). The CTD observations were carried out with a SBE-19plus CTD that was calibrated prior to the expedition, and was accurate to $\pm 0.005^{\circ} \mathrm{C}$ and $\pm 0.0005 \mathrm{~S} \mathrm{~m}^{-1}$. The CTD was outfitted with a Seapoint Turbidity Meter that measured turbidity in nephelometric turbidity units (NTUs). Additionally we used vertical profiles of the colored dissolved organic matter (CDOM) from an Ice Tethered Profiler (ITP) by McLane Research Laboratory that was temporarily deployed at SN15-13 from 21 April to 11 May (Fig. 4b). The ITP collected a profile every $2 \mathrm{~h}$ between 3 and $101 \mathrm{~m}$ depth and was equipped with a Wetlabs ECO sensor for measuring backscatter intensity, chlorophyll fluorescence and CDOM fluorescence for $\mathrm{EX} / \mathrm{EM}=370 / 460 \mathrm{~nm}$. CDOM data were recorded approximately every $1.5 \mathrm{~m}$ with sensitivity of 0.28 parts per billion ( $\mathrm{ppb}$ ). Other ITP data from this temporary deployment are not used within this paper.

Four sets of complementary CTD profiles are used to provide context for the water masses we observed over the Wandel Sea shelf. CTD profiles collected in the Beaufort Sea between 225 and $226^{\circ} \mathrm{E}$ between June and October from 2002 to 2011 by ArcticNet (Fig. 1) were averaged and reveal the mean summer water profile in the Beaufort Sea, which we consider the "upstream" area. CTD profiles collected over the Wandel Sea continental slope during June and July 2015 from the research hovercraft SABVABAA during the Norwegian FRAM 2014-2015 sea-ice drift (Fig. 2b) are used to represent the ambient water masses and compared against a CTD profile collected in August 2008 from the RV Polarstern (Kattner, 2009). Furthermore we adopted a CTD profile taken in a rift in the 79 North Glacier in August 2009 - Fig. 2b (Straneo et al., 2012).

Ice conditions over the Wandel Sea shelf, the adjoining fjords and the Greenland Sea continental slope were monitored by MODIS (Moderate Resolution Imaging Spectroradiometer - Fig. 2b) and Sentinel-1 C-band SAR (C-Band 

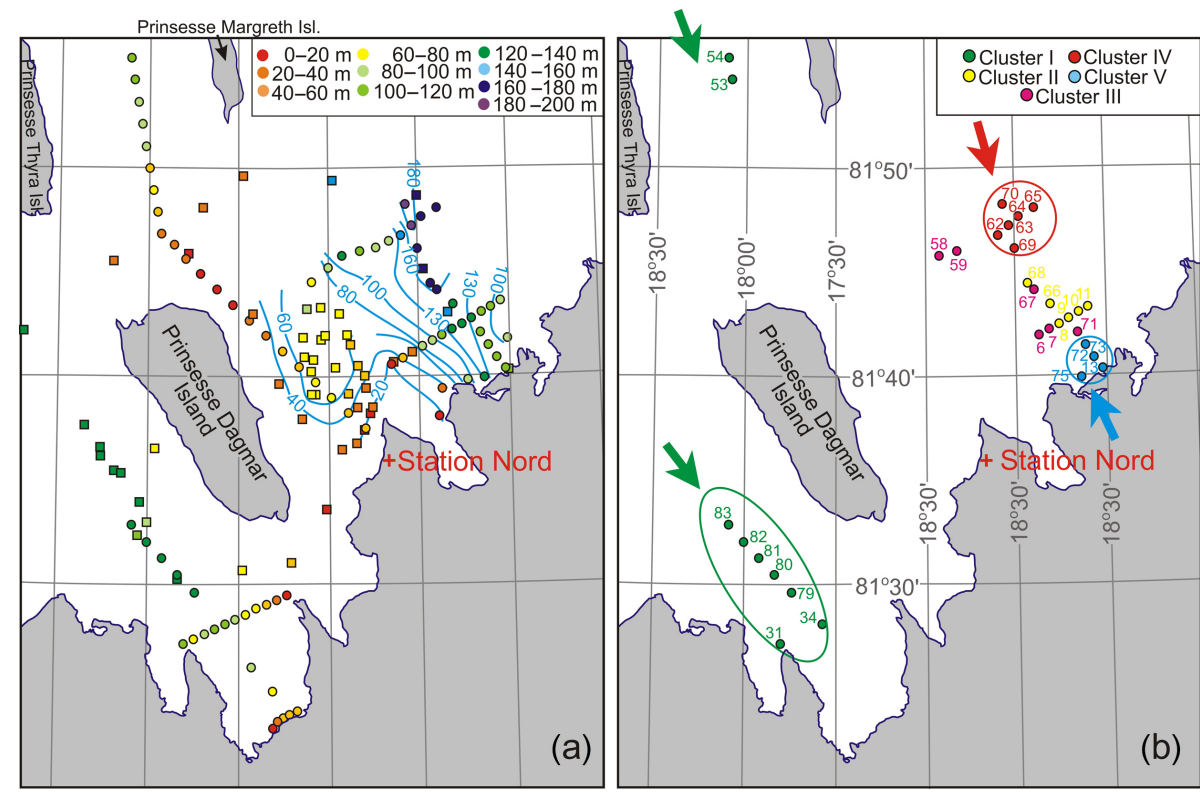

Figure 4. CTD stations occupied in April-May 2015 (circles). (a) Depth shown by color and blue contour lines. In addition, squares identify stations with depth measured in May 2006 (adopted from Nørgaard-Pedersen et al., 2008) and April 2015. (b) CTD stations > 100 m depth are grouped in clusters derived from the TS analysis. They are identified by their station numbers. Arrows depict deep water pathways.

Synthetic Aperture Radar - Fig. 3) satellite imagery, acquired daily by the Danish Meteorological Institute (http:// ocean.dmi.dk/arctic/nord.uk.php). In general, newly formed sea-ice, ice ridges, multiyear and first-year landfast sea ice, refrozen leads, large icebergs, and glacier terminations are distinguishable in SAR imagery. Sea-ice thickness was measured manually at each CTD station with an ice thickness tape.

Within this study we are interested in resolving the vertical thermohaline structure below the freshened surface waters, including the water layer below the lower boundary of the glacier tongue ( $>\sim 90 \mathrm{~m} \mathrm{depth}$ ) and a warmer Atlanticderived water layer with temperature $>0{ }^{\circ} \mathrm{C}$ below $\sim 140 \mathrm{~m}$ depth. Therefore we only use the $31 \mathrm{CTD}$ profiles that were collected in waters deeper than $100 \mathrm{~m}$ (Fig. 4). Over the Wandel Sea shelf there are three regions with depths greater than $100 \mathrm{~m}$. These regions are separated laterally by $\sim 20-30 \mathrm{~m}$ deep shoals, but are likely connected to submarine troughs that lead towards the continental slope (Nørgaard-Pedersen et al., 2008).

The primary region with depth exceeding $100 \mathrm{~m}$ is located over a submarine glacial trough to the north-northeast of Station Nord that ranges in depth from 110-130 $\mathrm{m}$ at the tidewater glacier outlet (STN15-13 and 75) to $183 \mathrm{~m}$ further off-shore along the trough (STN15-63; Fig. 4). The glacial trough has been formed by the Flade Isblink ice cap (e.g., Palmer et al., 2010; Rinne et al., 2011). During our surveys this area was predominantly covered by landfast multiyear sea ice $(\sim 3.5 \mathrm{~m}$ thick; lighter colors in Fig. 3$)$. Several CTD stations were performed through refrozen leads that contained younger and therefore thinner sea ice $(\sim 1.5 \mathrm{~m}$ thick; darker colors in Fig. 3). The glacial trough was paralleled on both sides by numerous icebergs that appeared to be grounded on the marginal lateral moraine which can significantly suppress lateral exchange with ambient water from the continental slope (Fig. 3). However, lateral exchange still might be possible given the narrow glacial troughs that exist across these shallow shoals (Nørgaard-Pedersen et al., 2008).

Another area with depth exceeding $100 \mathrm{~m}$ is located to the northwest of Station Nord between Prinsesse Thyra and Prinsesse Margreth islands with depths of 104-112 m (stations STN15-53/54; Fig. 4). The region was covered by $\sim 1.2 \mathrm{~m}$ of sea ice that grew within a refrozen lead after it opened in August 2012 (Fig. 3). We speculate that the gradual increase in depth along the CTD transect that ended at STN15-54 continues out along the trough towards the continental slope; however, no bathymetric data are available beyond STN15-54.

The glacial trough to the west-southwest of Station Nord from the glacial outlet of the Flade Isblink ice cap to the west of Prinsesse Dagmar Island also exceeds $100 \mathrm{~m}$ depth (Fig. 4a). During our field work the glacier was grounded at $\sim 35-40 \mathrm{~m}$ depth. The trough extending from this outlet glacier quickly reached depths of $\sim 100 \mathrm{~m}$ (STN15-35) and reached a maximum depth of $127 \mathrm{~m}$ (STN15-79). During the field campaign this region was covered with a mix of first-year $(\sim 1.2 \mathrm{~m}$ thick $)$ and multiyear sea ice $(\sim 3 \mathrm{~m}$ thick), with icebergs and an ice island frozen within the fast ice (Fig. 3) that corresponds to the typical ice conditions over this area. During August 2014 (Fig. 2) as well 


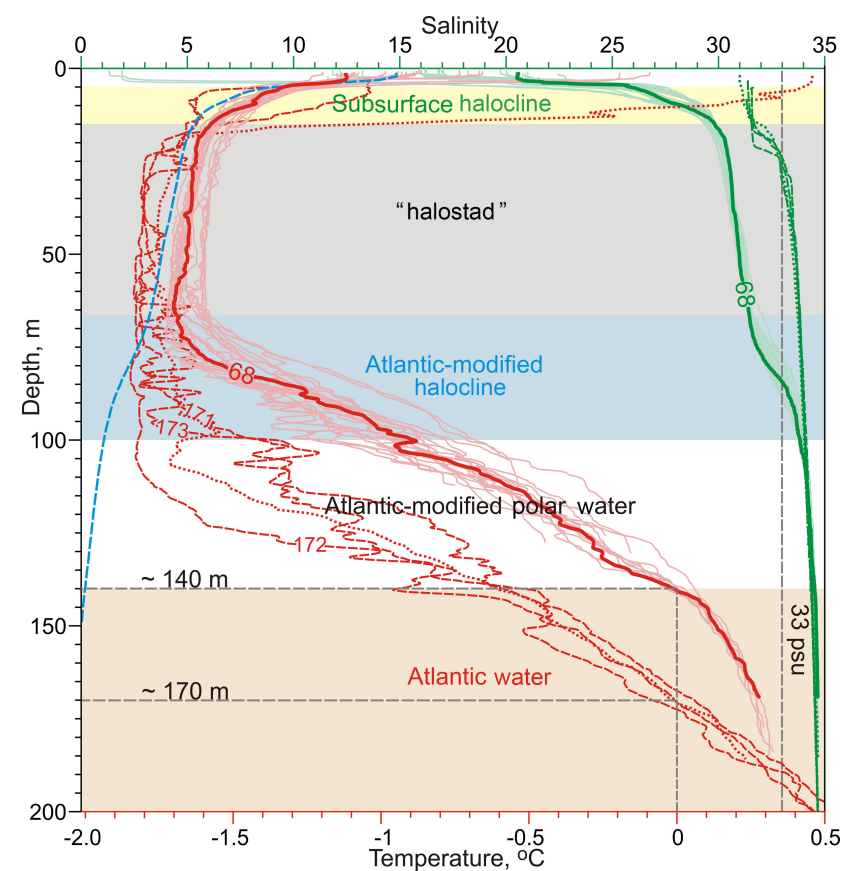

Figure 5. Vertical distribution of temperature (red) and salinity (green) profiles over the Wandel Sea shelf ( $\geq 100 \mathrm{~m}$ depth; solid curves) from April and May 2015, over the continental slope (stations 171-173; dashed curves) from June and July 2015 from the Norwegian FRAM 2014-2015 ice drift (see Fig. 2b for station position) and on the Wandel Sea upper continental slope (ARKXXIII/2 268; dotted curves) from RV Polarstern on $2 \mathrm{Au}$ gust 2008 (Kattner, 2009). Thick red and green lines show typical vertical profiles of salinity and temperature, respectively, for station STN15-68. The blue dashed curve is the in situ temperature of freezing computed using the mean SN salinity profile (not shown). The vertical dashed line depicts salinity of 33 that separates the PcW and AW in the western Beaufort Sea (von Appen and Pickart, 2012).

as during August 2010-2012 this region was ice-free (http: //ocean.dmi.dk/arctic/nord.uk.php).

\section{Results}

\subsection{Water mass structure}

The water column over the Wandel Sea shelf shows six distinct layers (Fig. 5). The layer immediately below the ice $(\sim 1.5-5 \mathrm{~m})$ was relatively fresh (salinity of 16-21; Fig. 5) as a result of summer snow and sea-ice meltwater and freshwater from the glacial runoff (Bendtsen et al., 2017). Several stations had extremely fresh surface waters (salinity of 1-12; Fig. 5) that appeared to be part of under-ice ponds (e.g. Eicken, 1994; Flocco et al., 2015) comprised of meltwater trapped in pockets below the multiyear landfast ice. This surface layer freshened during the melt season and was observed to have salinities of 1-8 during CTD transects in August 2015 (Bendtsen et al., 2017). The subsurface halocline layer is characterized by a strong vertical salinity gradient (salinity $1 \mathrm{~m}^{-1}$ ) down to $15 \mathrm{~m}$ depth (Fig. 5). The subsurface halocline separated the fresh surface waters from a layer with weak vertical salinity gradients (salinity 30 to 31.2 ) and water near the freezing point (blue dashed line Fig. 5) that reached to $\sim 65 \mathrm{~m}$ depth (Fig. 5). Shimada et al. (2005) identified this layer in the Canada Basin and referred to it as a "cold halostad", thus over the Wandel Sea shelf we refer to this layer as the "halostad" (Fig. 5, Table 1).

Below the halostad (below $75 \mathrm{~m}$ depth), temperatures increased steadily through the halocline (with salinity centered around 33) and Atlantic modified polar water (PrW) - Fig. 5 and Table 1. The halocline is further distinguished from the halostad and PrW by its high vertical salinity gradient of $0.07 \mathrm{~m}^{-1}$ (Fig. 5). Temperatures eventually exceeded $0^{\circ} \mathrm{C}$ (the commonly accepted upper boundary of the Atlantic layer) at $\sim 140 \mathrm{~m}$ depth, indicating the presence of Atlantic Water (AW) below this depth (Table 1). Atlantic modification of the halocline is evident from the increase in temperature through the halocline. Furthermore, the halocline shows intrusions of cooler water, which is further described and discussed for tracing the shelf-slope and ocean-glacier interactions, as well as the Pacific water $(\mathrm{PcW})$ and $\mathrm{AW}$ outflow from the Arctic Ocean through the western Fram Strait.

Comparing CTD profiles collected over the Wandel Sea shelf (solid lines) and those collected off-shelf (dashed lines) reveals substantial differences in the temperature profiles down to $180 \mathrm{~m}$, and in the salinity profiles down to $110 \mathrm{~m}$ (Fig. 5). In 2015, the halostad and halocline over the Wandel Sea shelf were not observed over the continental slope (Fig. 5). Moreover, the thermocline was typically $20-30 \mathrm{~m}$ deeper off the shelf (red dashed lines Fig. 5); specifically, the upper boundary of the AW was found at $170 \mathrm{~m}$ compared to $140 \mathrm{~m}$ on the shelf. We also present a CTD profile collected on the upper continental slope in 2008 (dotted lines in Fig. 5), which reveals little variability in the water mass structure between 2008 and 2015 and indicates that the off-shelf water mass structure is characterized by a colder, thicker and more saline halostad that is derived from the lower halocline in the Nansen Basin (Rudels et al., 1996). We note, however, that the synoptic, seasonal and interannual variability can be significant (e.g., Falck et al., 2005) making it difficult to interpret the snapshot data from the Wandel Sea continental slope, while this analysis appears to be important and plausible.

\subsection{CTD clustering}

\subsubsection{Methods of CTD clustering}

In the following, we focus on the water layer below the subsurface halocline, comprised of the halostad, halocline, PrW and AW layers (Figs. 5-7, Table 1). The 31 CTD profiles with depths greater than $100 \mathrm{~m}$ were subdivided into clusters according to their temperature-salinity (TS) curves and their variability in the TS space (Figs. 4b, 6 and 7 and Ta- 
Table 1. The Wandel Sea water mass structure below $15 \mathrm{~m}$ depth.

\begin{tabular}{llrlrr}
\hline \multirow{2}{*}{ Water layer } & \multirow{2}{*}{ Acronym } & \multicolumn{4}{c}{ Property range } \\
\cline { 3 - 6 } & & Depth, $\mathrm{m}$ & Temperature, ${ }^{\circ} \mathrm{C}$ & Salinity & $\sigma_{0}, \mathrm{~kg} \mathrm{~m}^{-3}$ \\
\hline Halostad (of Pacific origin) & - & $\sim 15-65$ & $\sim-1.5$ to -1.75 & $30-31.2$ & $24.1-25.1$ \\
Pacific water & PcW & & PcW comprises the halostad & \\
Halocline & - & $\sim 65-100$ & $\sim-1.75$ to -0.65 & $31.2-34$ & $25.1-27.3$ \\
Atlantic-modified polar water & PrW & $\sim 100-140$ & $-1.15-0$ & $34-34.5$ & $27.3-27.7$ \\
Atlantic Water & AW & $>140$ & $>0$ (up to 0.3$)$ & $>34.5$ & $>27.7$ \\
\hline
\end{tabular}

Table 2. Description of the Wandel Sea CTD clusters.

\begin{tabular}{|c|c|c|c|c|c|c|c|}
\hline \multirow[t]{2}{*}{ Cluster no. } & \multirow[t]{2}{*}{ Cluster name } & \multirow[t]{2}{*}{ Station no. } & \multirow[t]{2}{*}{ Main features } & \multicolumn{4}{|c|}{ Property range } \\
\hline & & & & $\begin{array}{r}\text { Depth } \\
\mathrm{m}\end{array}$ & $\begin{array}{r}\text { Temperature } \\
{ }^{\circ} \mathrm{C}\end{array}$ & Salinity & $\mathrm{kg} \mathrm{m}^{-3}$ \\
\hline I & Open water & $\begin{array}{l}31,35 \\
53,54 \\
79-83\end{array}$ & $\begin{array}{l}\text { "Warm" halostad } \\
\text { Smooth TS curves }\end{array}$ & $\begin{array}{r}15-65 \\
>65\end{array}$ & $\begin{array}{r}\sim-1.6 \\
-1.7 \text { to }-0.8\end{array}$ & $\begin{array}{r}30.0-31.2 \\
>31.2\end{array}$ & $\begin{array}{r}24.2-25 \\
>25\end{array}$ \\
\hline II & Basic & $\begin{array}{l}8-11 \\
66,68\end{array}$ & $\begin{array}{l}\text { "Cold" halostad } \\
\text { Smooth TS curves }\end{array}$ & $\begin{array}{r}15-65 \\
>65\end{array}$ & $\begin{array}{r}-1.6 \text { to }-1.72 \\
-1.7 \text { to }-0.8\end{array}$ & $\begin{array}{r}30.0-31.2 \\
>31.2\end{array}$ & $\begin{array}{r}24.2-25 \\
>25\end{array}$ \\
\hline III & Transit & $\begin{array}{l}6,7 \\
58,59 \\
67,71\end{array}$ & $\begin{array}{l}\text { Moderate intrusions } \\
\text { with temperature } \\
\text { anomalies }<1 \mathrm{SD}\end{array}$ & $65-90$ & -1.25 to -1.6 & $31.2-33.5$ & $25.6-26.7$ \\
\hline IV & Intrusive & $\begin{array}{l}62-65 \\
69,70\end{array}$ & $\begin{array}{l}\text { Significant intrusions } \\
\text { with negative } \\
\text { temperature } \\
\text { anomalies }>1 \mathrm{SD}\end{array}$ & $65-90$ & -1.25 to -1.7 & $31.2-33.5$ & $25.3-26.7$ \\
\hline V & Glacier & $\begin{array}{l}13,73 \\
73,75\end{array}$ & $\begin{array}{l}\text { Significant intrusions } \\
\text { Deflected mixing line }\end{array}$ & $\begin{array}{r}90-100 \\
>100\end{array}$ & $\begin{array}{r}-1.2 \text { to }-1.4 \\
>-1.2\end{array}$ & $\begin{array}{r}33.5-33.85 \\
>33.85\end{array}$ & $\begin{array}{l}>27.1 \\
>27.2\end{array}$ \\
\hline
\end{tabular}

ble 2). The clustering was conducted to assess the origin of water masses, and to identify the shelf-slope and oceanglacier interactions. For clustering we use the following criteria. (i) For the salinity range $30<S<31.2(\sim 15-65 \mathrm{~m}$ depth; halostad; gray shaded area Fig. 6) we differentiate profiles based on their proximity to the freezing temperature (blue dashed line Fig. 6), which indicates how the water thermal properties have been modified. (ii) For the salinity range $31.2<S<33.5$ ( $\sim 65-90 \mathrm{~m}$ depth; upper halocline; green shaded area Figs. 6 and 7) we differentiate clusters based on the appearance of distinctive thermohaline intrusions within the TS curves. These intrusions increase the TS variability and disrupt the initially smooth TS curves, which indicate interaction between ambient water masses. These features have been used to trace the origin and pathways of water masses in the Arctic Ocean (e.g., Walsh and Carmack, 2003; Rudels et al., 1994, 2005; Woodgate et al., 2007) and identify shelf-glacier interactions (Jenkins, 1999; Stevens et al., 2016). (iii) For the salinity range > 33.5 (>90 $\mathrm{m}$ depth; low halocline; pink shaded area; Figs. 6 and 7) we use the appearance of thermohaline intrusions and the slope of the mixing line to differentiate the clusters (Fig. $7 \mathrm{~d}$ and e). The displacement of the mixing line indicates the thermodynamic "meltwater" endmember (e.g., Jenkins, 1999; Straneo et al., 2012; Wilson and Straneo, 2015).

The intrusions along isohalines suggest isopycnal interleaving occurs within the area (Figs. $6 \mathrm{~b}$ and $7 \mathrm{c}$ ). Thus, one along-isopycnal standard deviation of the mean temperature and salinity was employed to estimate the efficiency of intrusive activity for every $0.1 \mathrm{~kg} \mathrm{~m}^{-3}$ interval of the potential density. All TS curves exceeding $\pm 1 \mathrm{SD}$ (standard deviation) at more than $50 \%$ of the $0.1 \mathrm{~kg} \mathrm{~m}^{-3}$ intervals were added to the different clusters based on the prescribed salinity range. We also defined a "transit" cluster (Fig. 7b) showing weak thermohaline intrusions below 1 standard deviation of the mean.

Based on our criteria, all CTD profiles $\geq 100 \mathrm{~m}$ depth were subdivided into five clusters (Table 2 and Figs. 4b, 6 and 7). 


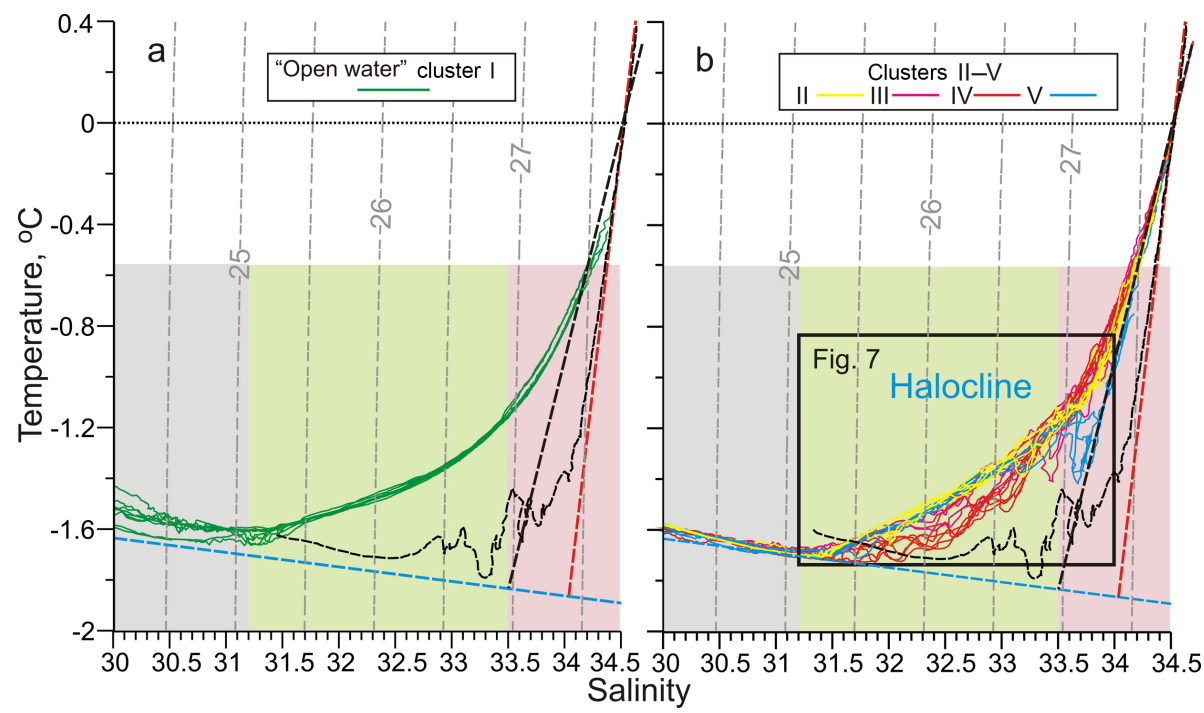

Figure 6. In situ temperature and salinity curves for the CTD stations $>100 \mathrm{~m}$ depth with $\sigma_{0}$ isopycnals presented (dashed grey lines; $\mathrm{kg} \mathrm{m}^{-3}$ ). (a) CTD profiles grouped into Cluster I, "open water". (b) CTD profiles grouped into Clusters II-V. The halocline layer of the water column is enlarged in Fig. 7 where Clusters II-V are distinguished. We also present an approximation of thermohaline properties for the downstream Atlantic-modified PrW over the NEW continental slope (dashed red line; adopted from Falck, 2001) and the profile from Station 172 over the Wandel Sea continental slope (thin black dashed line). The surface freezing temperature is also presented (dashed blue line). An approximation of the meltwater mixing line from interaction with the glacial tongue is derived from Cluster V by fitting the data in TS space (thick black dashed line). The panels are shaded according to the corresponding water masses; gray represents the halostad, while green and pink represent the halocline and define the salinity used for clustering.

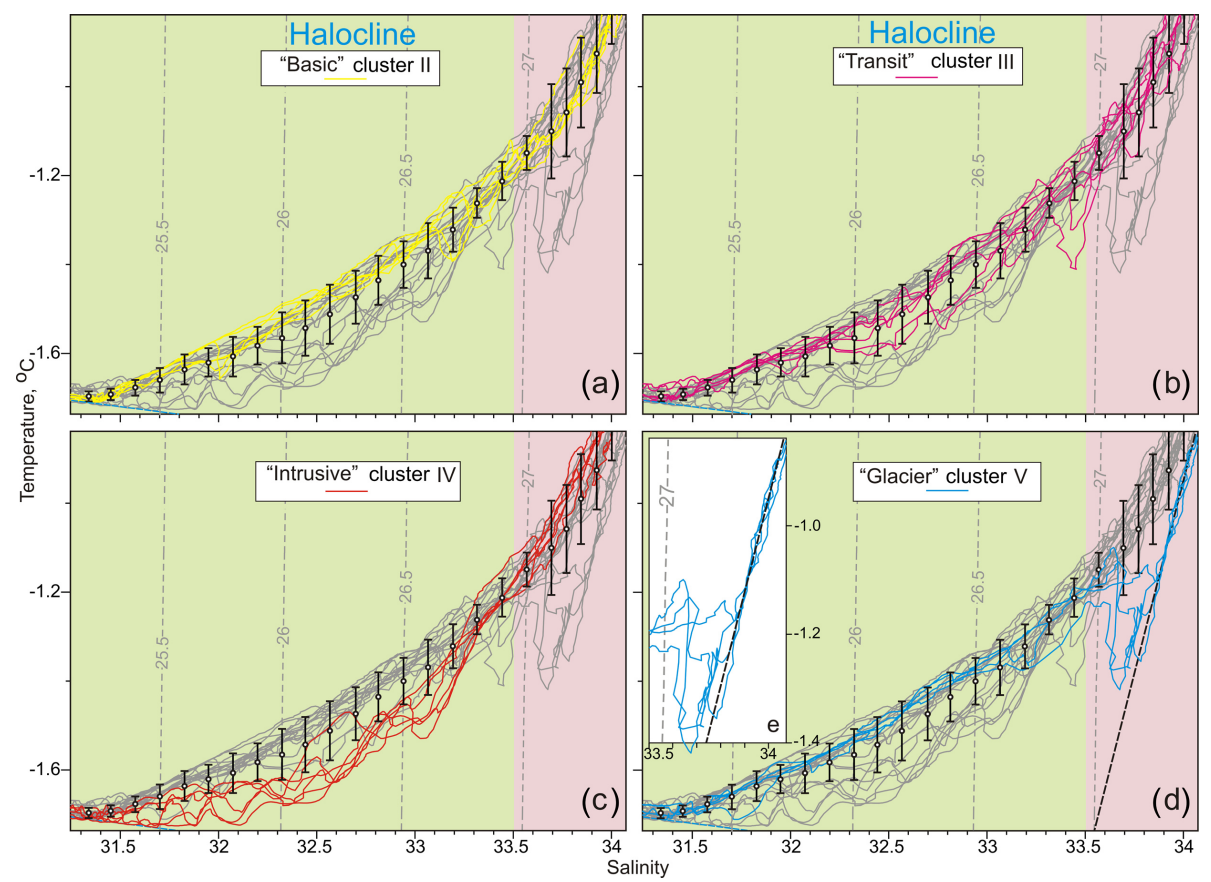

Figure 7. In situ temperature and salinity curves for the CTD profiles grouped into Clusters (a) II (yellow), (b) III (purple), (c) IV (red) and (d) V (blue) overlaid over the profiles from other clusters (grey). The mean TS characteristics \pm 1 SD (white barred dots) are presented at isopycnal intervals of $0.1 \mathrm{~kg} \mathrm{~m}^{-3}$. All other designations are similar to those in Fig. 6. (e) Temperature and salinity curves below the glacier depth for the CTD profiles grouped into Cluster V. 


\subsubsection{Description of clusters}

Here we assess the main patterns of clusters, putting them in the context of their geographical location on the Wandel Sea shelf and the sea-ice features.

Cluster I is comprised of the nine CTD stations situated (i) along the glacial trough to the west-southwest of Station Nord and (ii) between Prinsesse Thyra and Prinsesse Margreth islands (SN15-31/35/53/54/79-83; Figs. 4b and 6a). This cluster is distinguished by two features: (i) a relatively warm halostad overlying the halocline above $65 \mathrm{~m}$ $(30<S<31.2)$ and (ii) smooth TS curves through the underlying water column $(S>31.2)$ that appear to be unaffected by intrusive activity (Fig. 6a). The highest temperature offset from the potential freezing temperature is associated with CTD profiles from the glacial trough, which was ice-free during the preceding summer (Fig. 2b) and therefore warmed through solar heating. Region between islands was most recently ice-free during August 2013 (not shown), which likely led to the creation of a relatively warm subsurface layer. Thus, we subsequently refer to Cluster I as the "open water" cluster.

Cluster II (6 stations: SN15-8-11/66/68; Figs. 4b, 6b and 7a) is characterized by smooth TS curves slightly affected by intrusive activity (Fig. 7a), with water near the potential freezing temperature in the halostad $(S<31.2$; gray shading in Fig. 6b). Stations from this cluster occupy the middle of the glacial trough to the north of Station Nord and were covered by multiyear landfast ice during our field program. In the following we assume that Cluster II represents the background oceanographic conditions over the Wandel Sea shelf, and subsequently refer to this group as the "basic" cluster.

Cluster III (6 stations: SN15-6/7/58/59/67/71; Figs. 4b, $6 \mathrm{~b}$ and $7 \mathrm{~b}$ ) is characterized by temperatures that remain within 1 SD through salinities between 31.2 and 33.5 (green shaded area, Figs. $6 \mathrm{~b}$ and $7 \mathrm{~b}$ ), except for two profiles that deviate from the mean by -0.1 to $-0.2{ }^{\circ} \mathrm{C}$ along the $26.9 \pm 0.1 \mathrm{~kg} \mathrm{~m}^{-3}$ isopycnal. In general, stations from Cluster III occupy almost the same area as Cluster II (Fig. 4b) and represent the transition from Cluster II, with smooth TS curves, to Cluster IV, strongly impacted by intrusive activity. Thus, we refer to this cluster as the "transit" cluster.

Cluster IV (6 stations: SN15-62-65/69/70; Figs. 4b, 6b and $7 \mathrm{c}$ ) profiles display the most significant intrusive activity within the halocline between salinities of 31.2 and 33.5 (Figs. $6 \mathrm{~b}$ and $7 \mathrm{c}$ ). Within this range all TS curves show negative temperature anomalies greater than 1 standard deviation for at least half of the $0.1 \mathrm{~kg} \mathrm{~m}^{-3}$ intervals (Fig. 7c). In contrast, the profiles from this cluster have positive temperature anomalies of about 1 standard deviation throughout the underlying water where $S>33.5$. Profiles from this cluster were taken over the compact area on the eastern flank of the glacial trough on the Wandel Sea outer shelf (Fig. 4b) and are the closest profiles to the continental slope. Hereafter we refer to these stations as the "intrusive" cluster.

Cluster V (4 stations: SN15-13/72/73/75; Figs. 4b, 6b and $7 \mathrm{~d}$ ) is characterized by profiles that (i) show exceptionally strong intrusive activity in the TS plot for $33.5<S<33.85$ (90-100 $\mathrm{m}$ depth) and (ii) comprise a new mixing line for the underlying water layer $(S>33.85$, $>100 \mathrm{~m}$ depth), which is remarkably different from the ambient Clusters II-IV (Fig. 7d and e). For stations SN15-13/72/75, thermohaline intrusions show densitycompensated negative salinity/temperature anomalies of up to $-0.03 /-0.32{ }^{\circ} \mathrm{C}$, and exceed the mean by more than 2 standard deviations. Station SN15-73 shows smaller intrusions, but they still exceed the mean by about 1 standard deviation. For $S>33.9$, profiles from this cluster align with a distinct mixing line that is shifted towards lower temperatures relative to the ambient profiles. Profiles from this cluster were collected near the front of the glacial tongue, and thus we refer to this cluster as the "glacier" cluster.

\section{Discussion}

Below we discuss the potential origin and modifications of the water masses in clusters II, IV and V that we have identified over the Wandel Sea shelf. We also use our findings to trace the Arctic Ocean outflow through the western Fram Strait, putting our results into the context of upstream observations in the Canada Basin and downstream observations in the Northeast Water Polynya (NEW).

\subsection{Shelf water interaction with tidewater glacier}

We speculate that cluster $\mathrm{V}$ shows features that we attribute to the ocean-glacier interaction. These are (i) the abnormal intrusive activity at the base of the halocline and (ii) the transition of profiles in the TS space towards a new mixing line for the underlying Atlantic modified PrW at the glacier front (Fig. 7d and e). The ambient water from Clusters II-IV exhibits a background mixing line between the halocline and AW (Fig. 6b) which seems to be unaffected by the ocean-glacier interaction. During summer, significant surface glacial runoff provides a new endmember to this mixture. However, during winter there is no surface glacial runoff, and subglacial runoff is negligible, as confirmed by our CTD profiles during April and May, which show no surface salinity gradient around the termination of the glacier. Even though glacial meltwater is negligible during winter, the glacier can still modify the ambient mixing line through ocean-glacier interactions, as we will discuss below.

Water cools when it comes in contact with glacier ice that is colder than the in situ freezing point. For example, for the Ross Ice Shelf in Antarctica, Wexler (1960) reported that the glacier ice temperature increased from $-22^{\circ} \mathrm{C}$ at the surface to $-14{ }^{\circ} \mathrm{C}$ at $200 \mathrm{~m}$ depth and to $-1.7^{\circ} \mathrm{C}$ at the glacier- 
ocean interface at $\sim 260 \mathrm{~m}$ depth. For the Flade Isblink ice cap outlet, the cold glacier can significantly affect the water column below the floating glacier tongue, generating a new water mass that can be colder than the ambient PrW modified by interaction with the underlying warm AW. The subglacier freshwater discharge can also reduce the salinity of this water mass; however, the subglacier discharge is likely negligible during winter. For the floating glacier, a lateral interaction between the water below the glacier tongue and the Atlanticmodified PrW can (i) give rise to the intrusions we observed at the base of the halocline layer and (ii) modify the background mixing line towards colder temperatures as also observed (Figs. 6b and 7d). Similar intrusive interleavings at the front of a tidewater glacier were reported by Jenkins (1999), Mayer et al. (2000) and Stevens et al. (2016).

For station SN15-13, located $\sim 200 \mathrm{~m}$ from the termination of the tidewater glacier (Fig. 4b), the CTD profile shows an intrusion of cool, turbid water between 88 and $97 \mathrm{~m}$ depths that caused a temperature inversion of $-0.32^{\circ} \mathrm{C}$ and a sharp increase in the water turbidity from 0.2 to 1.5 NTU (Fig. 8). A similar rapid increase in turbidity with depth was also recorded at the Helheim Glacier in southeastern Greenland (Straneo et al., 2011). We attribute this increase to the lower boundary of the glacier tongue at $88 \mathrm{~m}$ depth. In this case the turbid water can be attributed to subglacial discharge, or submarine melting of ice-releasing sediments. The currents (3$5 \mathrm{~cm} \mathrm{~s}^{-1}$ as a maximum, Kirillov et al., 2017) are too weak for resuspending the $20 \mathrm{~m}$ thick bottom layer. Assuming the ratio of glacier to water densities to be 0.917 , we get a glacier elevation above the sea surface of $\sim 7.5 \mathrm{~m}$ that corroborates with our visual estimates.

At the front of the glacier termination, the water below the depth of the glacier tongue is on average cooler by $0.28^{\circ} \mathrm{C}$ and less salty $(\sim 0.2)$ than the ambient water as measured at SN15-09 (Cluster II; Fig. 8), suggesting a lateral heat flux along with an insignificant subglacier freshwater discharge in winter and/or a remnant of the larger discharge during summer. We suggest that interaction between the ambient shelf water and water below the glacier tongue, modified in direct contact with glacier ice, deflects the mixing line between the halocline and AW in the TS space towards a lower temperature and, to a lesser extent, to lower salinity values.

On the stations in cluster V, taken close to the tidewater glacier outlet, intrusions of colder, less saline water are observed around $90 \mathrm{~m}$ depth, which is the estimated lower boundary of the floating ice tongue. The water circulating below the glacier is initially warmer than the in situ freezing point of seawater and will be cooled as it gets in contact with the bottom of the glacier. The lost heat is partly used to melt ice and partly conducted into the glacier, increasing its temperature. Here we assume that the largest part of the heat goes to melting, and we presently ignore the fraction of heat conducted into the glacier. We also ignore all other freshwater sources, e.g. runoff and seasonal ice melt, except that due to melting of the glacier by ocean heat from below.

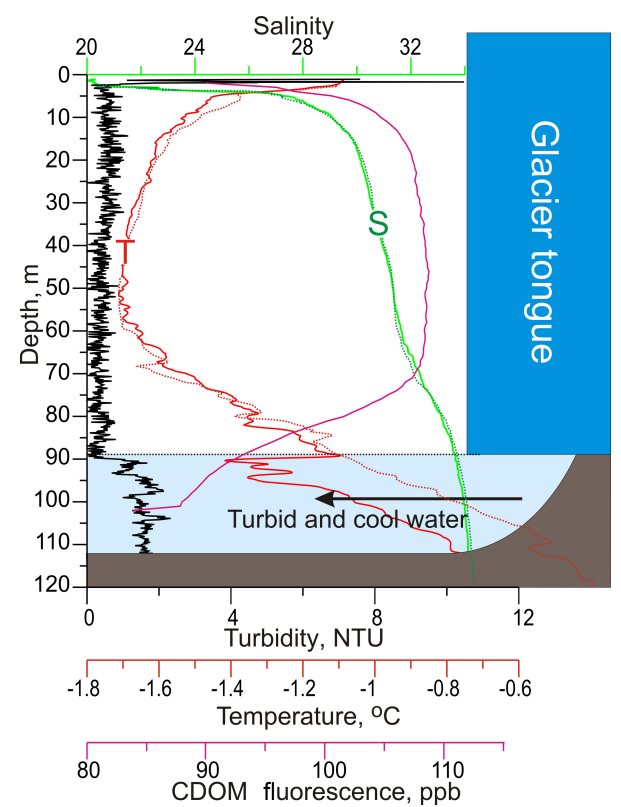

Figure 8. Vertical distribution of temperature $\left({ }^{\circ} \mathrm{C}\right.$, red), salinity (green) and turbidity (NTU, black) at station SN15-13 (Cluster V; solid lines) in front of the tidewater glacier. The CDOM fluorescence ( $\mathrm{ppb}$ ) from the moored ITP WETLabs Optical sensor shown for the 21 April-11 May mean (solid violet line) for the same location. An ambient profile from SN15-09 (Cluster II; dotted lines) is presented for comparison. The black dotted line at $\sim 90 \mathrm{~m}$ depth indicates the suggested depth of the glacier tongue. The glacier tongue is depicted schematically.

The density reduction of the ocean water due to added meltwater is larger than the density increase due to cooling, and the less saline water will ascend along the lower boundary of the glacier, until its terminus. At this point the water will penetrate into the ambient water column at its density level a few meters above the depth that the meltwater was released, forming colder, less saline isopycnal intrusions.

To describe the interactions occurring below the floating glacier to the first order we then assume that all heat lost by the water parcel is used to melt ice. The addition of meltwater leads to a salinity reduction $\Delta S$ that can be estimated from the following:

$$
\Delta S=\frac{S}{\left(\frac{L}{c_{p} \Delta T}-1\right)} .
$$

Here $c_{p}=3980 \mathrm{~J}^{\circ} \mathrm{C}^{-1} \mathrm{~kg}^{-1}$ is the heat capacity of seawater and $L=334500 \mathrm{~J} \mathrm{~kg}^{-1}$ is the latent heat of melting; $\Delta T$ is the temperature reduction and $S$ is the salinity of the water parcel re-emerging from underneath the glacier.

We do not have observations from below the floating glacier and we have to make assumptions both about the initial characteristics of the water entering below the glacier and the cooling and reduction of the salinity that occur by interaction with the glacier. The salinity of the water re-entering 
the water column from below the glacier is $S \sim 33.65$ and the observed temperature reduction, compared to the ambient profiles, is $\Delta T \sim 0.3^{\circ} \mathrm{C}$ (Figs. $4 \mathrm{~b}$ and $6 \mathrm{~b}$ ). We know that the initial salinity then has to be higher than 33.65. Looking at the ambient profiles (Fig. 5), we note that the mean temperature of the water that could possibly enter beneath the glacier is about $-0.8^{\circ} \mathrm{C}$. Assuming it is cooled to freezing temperature, $\Delta T$ is $1^{\circ} \mathrm{C}$ and $\Delta S$ becomes $\sim 0.4$. This gives an initial salinity of 34.05 to the water entering below the glacier.

However, the observed cold intrusions are not at the freezing point; instead they are warmer, around $-1.4^{\circ} \mathrm{C}$ (Fig. 8). This could indicate that the water entering below the glacier is not cooled to the freezing point, but only by $\sim 0.3{ }^{\circ} \mathrm{C}$. The initial salinity would then be 33.8 rather than 34.05 . Another possibility is that the cold water penetrates isopycnally into the water column and becomes warmer and more saline by mixing with ambient water. Assuming that the intrusions are isopycnal, the changes in temperature and salinity due to mixing becomes the following:

$\alpha \Delta T=\beta \Delta S$.

Here $\alpha=0.4 \times 10^{-4}{ }^{\circ} \mathrm{K}^{-1}$ is the coefficient for the heat expansion around $-1{ }^{\circ} \mathrm{C}$ and $\beta=8 \times 10^{-4} \mathrm{psu}^{-1}$ is the coefficient of salt contraction. A temperature change of $0.5^{\circ} \mathrm{C}$ then corresponds to a salinity change of 0.025 , making the salinity at the freezing point of 33.625 , close to the observed 33.65 at the intrusion and giving the initial salinity as 34.025 . This suggests that the intrusions observed on the stations close to the tidewater glacier outlet (Cluster V) might derive from the outflow of colder, less saline water created under the floating ice tongue due to interactions between the glacier and the underlying water masses.

\subsection{Shelf water interaction with ambient water from the continental slope}

We use the occurrence of intrusive interleaving as a tracer for the shelf-slope interaction. The intrusive halocline from Cluster IV was observed to the north of Station Nord (Fig. 4b) adjacent to the Greenland continental slope, where a water mass with different thermohaline properties is located (Fig. 5). The intrusions are indications of isopycnal interaction between the Atlantic-modified halocline occupied over the Wandel Sea shelf and a cooler PrW observed over the Wandel Sea continental slope (Fig. 5). Within the depth range of the halocline ( $\sim 65-100 \mathrm{~m})$, the cooler PrW is likely maintained by a weakened upward heat flux from the deepened AW in the off-shelf area. Over the Wandel Sea shelf, the upper AW boundary was recorded at $\sim 140 \mathrm{~m}$, while in JuneJuly 2015 and August 2008 it was $\sim 30 \mathrm{~m}$ deeper over the adjacent continental slope (Fig. 5). We note, however, that the water mass structure over the continental slope of northeastern Greenland shows significant interannual variability (e.g., Falck et al., 2005). Overall, the distinct difference between the on-shelf and off-shelf water mass structure (Fig. 5) suggests their different origins, which are further discussed in Sect. 4.3.

In the following we speculate that the intrusive halocline from Cluster IV is generated by interaction between the Atlantic-modified shelf halocline (Cluster II) and the PrW from the continental slope as shown in Fig. 9a. We suggest that this interaction is isopycnal because all intrusions are density compensated. For the halocline layer over the southern Wandel Sea continental slope, Rudels et al. (2005) reported an intrusive interleaving conditioned by isopycnal interaction between relatively warm halocline water from the upper continental slope and cold PrW from the lower continental slope.

For further interpretation of our results on the shelf-slope interaction we include 184 CTD profiles taken between 1992 and 1993 in the NEW area (Bignami and Hopkins, 1997; Budéus et al., 1997; Falck, 2001), which is downstream from the Wandel Sea shelf (Figs. 1 and 2b). The TS curves from the NEW area show two distinct modes: (i) the polynya (shelf) mode, which is similar to the "basic" Cluster II derived for the Wandel Sea shelf (Figs. 4b, 7a and dark blue lines in Fig. 9a) except for a slightly colder $\left(\sim 0.05^{\circ} \mathrm{C}\right)$ and saltier $(\sim 1)$ low halostad, and (ii) the continental slope mode, which within the salinity range of the Wandel Sea shelf halocline (31.2-34) shows a completely different shape of the TS curve (red lines in Fig. 9a). Specifically the TS line of the continental slope mode extends linearly through the halostad to salinity of $\sim 34$ (red dashed line in Fig. 9a; red rectangles in Fig. 9b), maintaining temperatures relatively close to the surface freezing temperature (blue dashed line Fig. 9b).

For the NEW area, the remarkable difference between the polynya (shelf mode) and the continental slope mode was also reported by Straneo et al. (2012) and Wilson and Straneo (2015), with a TS structure similar to the one presented in Fig. 9 (Fig. 3 from Wilson and Straneo, 2015). Moreover, for the $79 \mathrm{~N}$ glacier outlet (Fig. 2b), Straneo et al. (2012) used the upper continental slope CTDs as ambient stations and compared them to CTD profiles taken through a rift in the floating glacier tongue (see Fig. $2 \mathrm{~b}$ for the glacier station position). For the water layer at $\sim 40-90 \mathrm{~m}$ depth, they reported ambient water that was saltier than water below the glacier tongue by $\sim 1-2$, attributing this difference to the subglacier water discharge. We note, however, that this freshening is of the same magnitude as the salinity difference between the shelf halostad or halocline and the continental slope PrW (Fig. 9). Thus, freshening reported by Straneo et al. (2012) could be alternatively explained by the occurrence of the halostad-like freshened water layer below the glacier tongue.

In the following Sects. 4.3 and 4.4, we use the differences between the on-shelf and off-shelf water mass structures and the similarities between the Wandel Sea and NEW areas to trace the origin of the halostad, halocline and AW in the Wan- 


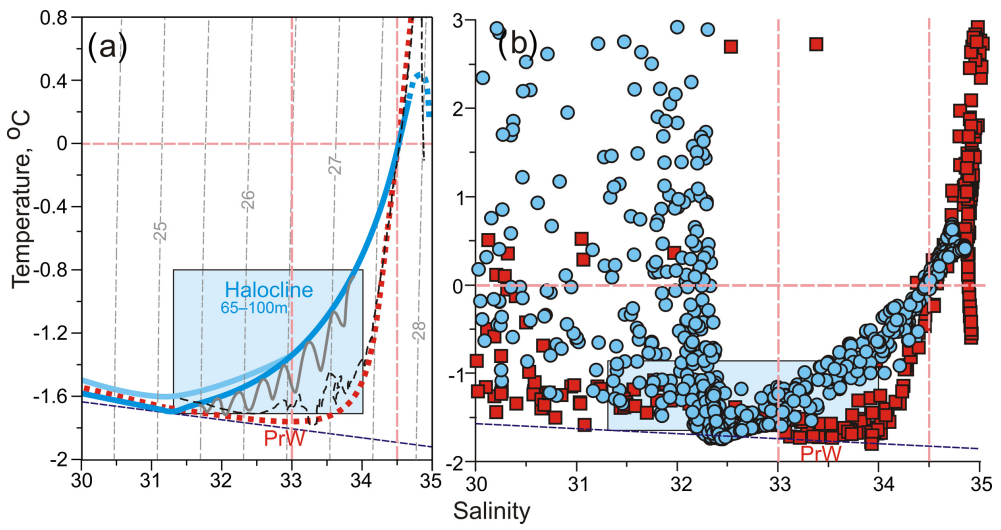

Figure 9. (a) Schematic showing formation of the intrusive halocline in clusters III and IV due to interleaving between the PcW (blue curve) and PrW (red dotted curve). Gray curve depicts the intrusive activity. The black dashed curve is station 172 from the Wandel Sea continental slope. The dashed red curve is approximation of the downstream PrW and AW properties at the Greenland continental slope, the NEW area adopted from (b). The solid dark/light blue curves are approximations of the PcW and upper AW from Clusters I/II. The dashed blue curve is approximation of the AW properties over the Greenland shelf in the NEW area adopted from (b). The gray dashed lines are $\sigma_{0}$ isopycnals in kilograms per cubic meter $\left(\mathrm{kg} \mathrm{m}^{-3}\right)$. (b) Temperature and salinity curves for the CTD stations taken in July-August 1993 between 76.5 and $81^{\circ} \mathrm{N}$ and west of $5^{\circ} \mathrm{W}$ over the NEW area after Falck (2001). Blue circles depict stations from the polynya (shelf) area. Red rectangular depict stations from the Greenland continental slope and Belgica Trough. (a, b) Blue shading highlights the approximate properties of the Wandel Sea shelf halocline. The dashed dark blue line is surface freezing temperature.

del Sea and their modification along the northeast Greenland coast.

\subsection{Tracing the origin of the Wandel Sea halostad, halocline and AW: local source}

The distinct difference between the on-shelf and off-shelf water mass structure and disposition suggests they have different origins and/or pathways to the Wandel Sea shelf and continental slope. The occurrence of the shelf halostad can be explained by local freshening by summer snow and sea-ice meltwater and freshwater from the glacier runoff. In turn, the uplifted on-shelf Atlantic-modified PrW and AW can originate from local modifications due to upwelling of AW over the Wandel Sea continental slope.

The under-ice surface layer over the Wandel Sea shelf is significantly freshened, potentially providing a source of freshwater for the freshened halostad over the shelf if vertical mixing overcomes the salinity (density) stratified subsurface halocline as was suggested for NEW by Bignami and Hopkins (1997). Among the Arctic shelves, the Wandel Sea subsurface halocline shows exceptionally strong vertical stratification, with salinity increasing from 18 to 30 across a $\sim 10 \mathrm{~m}$ thick subsurface halocline layer during winter (Fig. 5). This is comparable to the Laptev Sea shelf where strong salinity stratification is maintained by the river runoff from the Lena River, the second largest river flowing into the Arctic Ocean (e.g., Dmitrenko et al., 2010). Dmitrenko et al. (2012) showed that significant velocity shear over the Laptev Sea shelf, attributed to the lunar semidiurnal baroclinic internal tide M2 with velocity $\sim 15 \mathrm{~cm} \mathrm{~s}^{-1}$ at $11 \mathrm{~m}$ and $\sim 7 \mathrm{~cm} \mathrm{~s}^{-1}$ at $19 \mathrm{~m}$ depth is required to transform the vertically stratified water into a locally mixed layer. In contrast, over the Wandel Sea shelf velocities hardly exceed $3-5 \mathrm{~cm} \mathrm{~s}^{-1}$, and the most energetic M2 tidal currents are weak, decreasing from $\sim 2 \mathrm{~cm} \mathrm{~s}^{-1}$ beneath the ice to $\sim 1 \mathrm{~cm} \mathrm{~s}^{-1}$ below $60 \mathrm{~m}$ depth (Kirillov et al., 2017). Moreover, the multiyear landfast ice covering the Wandel Sea shelf precludes the wind stress from vertically mixing the stratified water column.

Hypothetically, the wind-driven upwelling of the Atlanticmodified PrW and AW over the continental slope can result in uplift of the water masses over the outer shelf. In this case, however, the shallowing of the Atlantic-modified PrW and the upper boundary of AW is accompanied by on-shelf inflow of the deeper and saltier water from the continental slope. In contrast, the Atlantic-modified halocline on the shelf is less salty compared to ambient water from the continental slope by $\sim 1-2$.

In the following we discuss our results in the context of upstream observations in the Canada Basin (e.g., Fig. 10) and downstream observations in the NEW region.

\subsection{Tracing the origin of the Wandel Sea halostad, halocline and AW: far-field advection}

We suggest that the on-shelf halostad and the associated halocline can be advected from the remote upstream areas where sources of freshwater exist. Similarly, as with the shelf halostad, the shallowed AW layer recorded over the Wandel Sea shelf and the deepened AW layer found over the continental slope should be attributed to the different branches of 


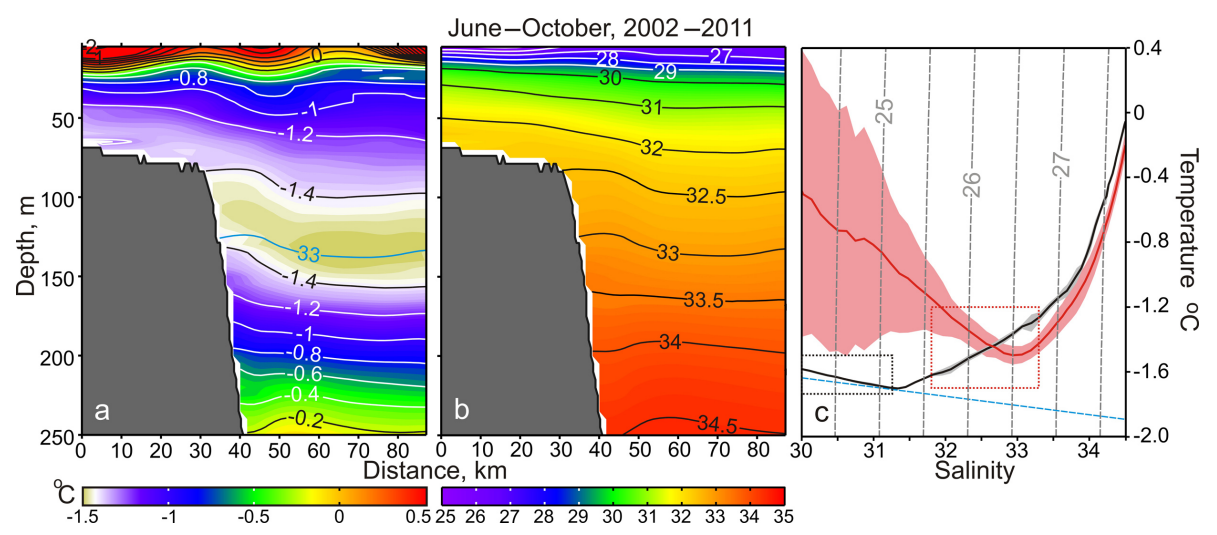

Figure 10. (a) Temperature $\left({ }^{\circ} \mathrm{C}\right)$ and (b) salinity distributions across the Beaufort Sea continental slope compiled based on 201 ArcticNet CTD profiles occupied between 225 and $226^{\circ} \mathrm{E}$ from June to October 2002-2011 (adopted from Dmitrenko et al., 2016). (c) In situ mean temperature and salinity curves for the cross-slope Beaufort Sea section (red) and the Wandel Sea shelf CTD profiles from the "basic" Cluster II (black). Shading depicts \pm 1 SD. The red and black dotted rectangles indicate thermohaline properties of the halostad over the Beaufort Sea continental slope and Wandel Sea shelf, respectively. The dashed blue line is surface freezing temperature. The gray dashed lines are $\sigma_{0}$ isopycnals in kilograms per cubic meter $\left(\mathrm{kg} \mathrm{m}^{-3}\right)$.

the AW outflow from the Arctic Ocean through the western Fram Strait.

The East Greenland Current carries the Arctic Ocean outflow through the western Fram Strait southward along the Greenland shelf and continental slope - Fig. 1 (e.g., Rudels et al., 2002; Jeansson et al., 2008). It transports cold, lowsalinity polar surface waters with $\sigma_{0} \leq 27.7 \mathrm{~kg} \mathrm{~m}^{-3}$ (Rudels et al., 2002) that are comprised of the river runoff and net precipitation water, but also of the less saline $\mathrm{PcW}$ that enters the Arctic Ocean through the Bering Strait (Jones et al., 1998, 2003, 2008; Rudels et al., 2002; Falck et al., 2005; de Steur et al., 2009; Sutherland et al., 2009) - Fig. 1. PcW within the Arctic Ocean is generally assigned to water with $S \leq 33$ (von Appen and Pickart, 2012) and has both a summer and winter signature based on its formation. The summer $\mathrm{PcW}$, with temperatures above $-1.2^{\circ} \mathrm{C}$ and salinities between 31 and 32 (Steele et al., 2004), is usually comprised of the Chukchi Summer Water (Woodgate et al., 2005) and the Alaskan Coastal Water (Pickart et al., 2005). Below the summer $\mathrm{PcW}$ is a layer of winter $\mathrm{PcW}$ that can be as cold as $-1.45^{\circ} \mathrm{C}$ and forms during sea-ice formation within the Bering and Chukchi seas (Jones and Anderson, 1986; Weingartner et al., 1998; Pickart et al., 2005).

It has been shown that the subsurface layer over the eastern Greenland coast is comprised of the PcW outflow from the Arctic Ocean (Jones et al., 1998, 2003, 2008; Falck, 2001; Falck et al., 2005; Jeansson et al., 2008; Sutherland et al., 2009). For the 1993 observations over the NEW shelf area, in the subsurface halostad layer down to $\sim 80 \mathrm{~m}$ depth, an average of about $90 \%$ is found to have Pacific origin (Falck, 2001). This result by Falck (2001) brought a different mechanism of the halostad formation to light. In contrast to Bignami and Hopkins (1997), Falck (2001) insists on an up- stream Pacific source for the halostad water and underlying halocline, rather than a local origin.

Upstream over the Canada Basin, PcW impacts the halocline structure, producing a double halocline with a "cold halostad" formed by the volumetric injection of the winter $\mathrm{PcW}$ that overlies low halocline water of Eurasian Basin origin (McLaughlin et al., 2004; Shimada et al., 2005). The salinity range of the cold halostad in the Canada Basin is $31.5<S<33.5$, with the lowest temperature of $\sim-1.7^{\circ} \mathrm{C}$ at the base of the halostad indicating the winter PcW (McLaughlin et al., 2004; Shimada et al., 2005). This water mass structure resembles that for the eastern Beaufort Sea continental slope (Fig. 10).

In general, the halostad structure over the Canada Basin and adjoining continental margin is similar to that recorded over the Wandel Sea shelf (Fig. 5). However, over the Wandel Sea shelf the halostad is cooler and fresher (Fig. 10c), occupying a salinity range of $30.0<S<31.5$. The Wandel Sea halostad is also shallower (15-65 $\mathrm{m}$ depth versus $\sim 50$ $200 \mathrm{~m}$ for the Canada Basin). The different salinity range of the halostad in the Wandel Sea and Canada Basin suggests that significant modifications occurred during transit of the winter PcW from the Bering and Chukchi seas to the Wandel Sea. It seems that the winter PcW is modified by vertical mixing with overlaying summer $\mathrm{PcW}$ and/or river runoff accumulated in the Canada Basin. For example, Jones et al. (2008) revealed that over the northeast Greenland coast at $\sim 81^{\circ} \mathrm{N}$, the $\mathrm{PcW}$ fraction is comparable with the river water fraction. Moreover, water from the Siberian shelves, especially the Laptev Sea shelf, also has the same salinity and temperature range (e.g., Dmitrenko et al., 2011) and can mix into and cool the summer PcW advected with the Transpolar Drift to the NE Greenland coast. This assumes that the river 
water impacts a Wandel Sea halostad initially comprised of the winter PcW.

The remote origin of the halostad is also confirmed by the elevated values of the CDOM fluorescence through the halostad layer at station SN15-13 (Fig. 8). The CDOM fluorescence is a good tracer of the Arctic Ocean terrigenous organic matter primarily attributed to the Eurasian and American continental runoff water (e.g., Granskog et al., 2012) as well as to interactions with sediments on the Arctic shelves (e.g., Guéguen et al., 2007). The CDOM fluorescence maxima in the halostad at station SN15-13 is consistent with results from the Canada Basin where this maxima is attributed to the winter PcW (e.g., Guéguen et al., 2007) and the continental river runoff water (e.g., Granskog et al., 2012). For the downstream NEW area, Amon et al. (2003) also reported the intermediate maxima of the CDOM fluorescence through the shelf halostad layer (Fig. 9a from Amon et al., 2003). Overall, this confirms the remote origin of the halostad layer over the Wandel Sea shelf and strengthens our discussion on the modification of the Pacific-derived halostad by river runoff while en route from the Canada Basin to the Fram Strait.

As the halocline and AW move along the Canada Basin margins toward northern Greenland, they ascend in the water column from 100-200 and 220-320 $\mathrm{m}$ in the Canada Basin (McLaughlin et al., 2004; Shimada et al., 2005) to 85 and $140 \mathrm{~m}$ on the Wandel Sea shelf, respectively (Fig. 5). Following Rudels et al. (2004), we speculate that this rise is due to the gradual thinning of the low-salinity layer above. The thinning could be caused by the upper layer either being confined to the Beaufort Gyre or draining through the Canadian Arctic Archipelago and ultimately into Baffin Bay (Rudels et al., 2004). This is consistent with a gradual shallowing of the upper boundary of AW traced by isopycnal $\sigma_{0}=27.4 \mathrm{~kg} \mathrm{~m}^{-3}$ from $\sim 230 \mathrm{~m}$ in the Canada Basin to $\sim 140 \mathrm{~m}$ in the Wandel Sea (Polyakov et al., 2010).

The occurrence of the Pacific origin halostad along the northeast Greenland coast suggests that $\mathrm{PcW}$ is transported southward by a narrow coastal branch of the East Greenland Current. This current also advects a shallowed AW, which likely originated from the Canada Basin branch (Fig. 1). The cross-slope interaction between the coastal and off-shelf branches of the East Greenland Current gives rise to the intrusive interleaving observed over the Wandel Sea outer shelf (Fig. 7c).

\section{Summary and conclusions}

The first-ever CTD observations over the Wandel Sea shelf and continental slope were collected in April-May and JuneJuly 2015, respectively. We use CTD profiles deeper than $100 \mathrm{~m}$ to focus on the origin of water masses, and to identify interactions between the shelf and slope, and between the ocean and outlet glaciers entering the Wandel Sea. The stations taken on the Wandel Sea shelf and farther to the east on the Greenland slope reveal two pathways for the advected water masses, one over the shelf and one along the continental slope. The one over the slope has warm, saline AW lying below a deep, cold, less saline and fairly homogenous upper layer that is capped by low-salinity surface water created by seasonal ice melt and heated by solar radiation. This suggests that AW recirculating within the Eurasian Basin (Fig. 1) with the less dense upper layer initially formed by sea-ice meltwater are mixed into the upper part of the entering AW. In the Nansen Basin this layer is homogenized by haline convection each winter (Rudels et al., 1996).

The water column found on the shelf has much colder and less saline AW located closer to the surface than the AW over the slope. The AW characteristics here are similar to those observed at much greater depth in the Canada Basin, indicating that this AW has circulated around the entire deep Arctic basins and now is returning towards the Fram Strait. In the Canada Basin, the AW is covered by the halocline layer and it is comprised of both Atlantic- $(S \sim 34)$ and Pacific-derived water, especially the Pacific Winter Water, with $S \sim 33.1$ (e.g., Jones and Anderson, 1986), as well as other low-salinity waters. These low-salinity waters lie shallower than the sill depth of the Canadian Arctic Archipelago and can pass through the straits into Baffin Bay. This would cause the AW to rise in the water column as it moves along the northern Canadian coast, until it is shallow enough to flow over deeper shelves like that of the Wandel Sea.

Over the Wandel Sea shelf, the Pacific Winter Water, that was so distinct in the Canada Basin, seems to be either missing or only occupying a narrow depth range. Instead the coldest water is found in the halostad with salinity around 31 instead of 33. The low-salinity upper layer and the thick ice cover in winter preclude the local homogenization of the water column down to the halostad. Thus, the halostad must be advected from elsewhere. A conceivable scenario could be that most of the PcW drains out of the Arctic Ocean through the Canadian Arctic Archipelago. This likely makes the AW ascend and it would allow water from the polar mixed layer, of Atlantic or Pacific origin, circulating in the Beaufort Gyre and in the Arctic basins to replace the water leaving through the straits in the archipelago and penetrate onto the shelf, creating a different upper layer above the AW.

Our findings are summarized as follows:

i. The subsurface (15-70 m depth) "cold halostad" layer with salinities of 30-31.5 and associated underlying halocline layer are distinct features of the Wandel Sea shelf hydrography. It does not persist over the Wandel Sea continental slope, indicating the water masses over the shelf and slope have different origins. A similar water mass structure was observed downstream in the Northeast Water Polynya area. This structure is likely maintained by the coastal branch of the Pacific water outflow from the Arctic Ocean, modified by interaction with river runoff water over the upstream Canada Basin. 
ii. The halocline layer centered at $\sim 80 \mathrm{~m}$ (salinity of $\sim 33$ ) separates the Pacific-origin cold halostad from the polar water, modified by interaction with warm Atlantic water outflow from the Arctic Ocean through the western Fram Strait. The upper boundary of the Atlantic Water $\left(T \sim 0{ }^{\circ} \mathrm{C}\right)$ is recorded at $\sim 170 \mathrm{~m}$ depth on the continental slope and $\sim 30 \mathrm{~m}$ shallower over the adjoining shelf. This difference suggests that, as with the subsurface layer, the intermediate water over the shelf and continental slope is conditioned by different branches of the Atlantic water outflow from the Arctic Ocean.

iii. The lateral shelf-slope interaction between on-shelf relatively warm Atlantic-modified halocline water and offshelf cold polar water gives rise to the intrusive interleaving observed over the Wandel Sea outer shelf.

iv. At the base of the halocline layer, cold and turbid water intrusions were recorded at the front of the tidewater glacier outlet. The temperature-salinity plots of the CTD profiles from this region show a mixing line that is deflected relative to the ambient water. Both features are likely conditioned by the ocean-glacier thermal interaction.

In summary, our analysis suggests the existence of a coastal branch of the East Greenland Current advecting Pacific water of Arctic origin southward along the northeast Greenland coast. This is consistent with an earlier proposition by Rudels et al. (2004), downstream observations along the southeast coast of Greenland (e.g., Bacon et al., 2002; Sutherland and Pickart, 2008; Sutherland et al., 2009) and numerical simulations (Hu and Myers, 2013; Aksenov et al., 2016). Finally, we note that our observations were not accompanied by water sampling for determining the nitrate-phosphate relationship commonly used to trace the Pacific water in the Arctic Ocean and Greenland Sea. This deficiency in the observational program conducted clearly shows the necessity for further research in this area using advanced methods of tracer analysis.

Data availability. For the Wandel Sea CTD data contact Igor Dmitrenko at igor.dmitrenko@umanitoba.ca.

Competing interests. The authors declare that they have no conflict of interest.

Acknowledgements. This study was funded by the Canada Excellence Research Chair program (SR), the Canada Research Chair program (DB), the Canada Foundation of Innovation, the National Sciences and Engineering Research Council of Canada (grant RGPIN-2014-03606, ID), the Manitoba Research and Innovation Fund, the University of Manitoba, Aarhus University, the Greenland Institute of Natural Resources, and the EU project NACLIM (grant agreement 308299, BR). We thank Ivali Lennert,
Kunuk Lennert and Egon Frandsen for technical assistance in the field. We also appreciate outstanding logistical support from the Station Nord Danish military personnel. John Mortensen (Greenland Climate Research Centre) provided valuable comments on the ocean-glacier interaction. Comments and editing by John K. Hall, the owner of the research hovercraft SABVABAA, are highly appreciated. Nils Nørgaard-Pedersen kindly provided bathymetric data used in Fig. 4a. This work is a contribution to the Arctic Science Partnership (ASP) and the ArcticNet Networks of Centres of Excellence programs.

Edited by: Mario Hoppema

Reviewed by: two anonymous referees

\section{References}

Aksenov, Y., Karcher, M., Proshutinsky, A., Gerdes, R., Cuevas, B., Golubeva, E., Kauker, F., Nguyen, A. T., Platov, G. A., Wadley, M., Watanabe, E., Coward, A. C., and Nurser A. J. G.: Arctic pathways of Pacific Water: Arctic Ocean Model Intercomparison experiments, J. Geophys. Res.-Oceans, 121, 27-59, https://doi.org/10.1002/2015JC011299, 2016.

Amon, R. M. W., Budéus, G., and Meon, B.: Dissolved organic carbon distribution and origin in the Nordic Seas: Exchanges with the Arctic Ocean and the North Atlantic, J. Geophys. Res., 108, 3221, https://doi.org/10.1029/2002JC001594, 2003.

Bacon, S., Reverdin, G., Rigor, I. G., and Smith, H. M.: A freshwater jet on the east Greenland shelf, J. Geophys. Res., 107, 3068, https://doi.org/10.1029/2001JC000935, 2002.

Bendtsen, J., Mortensen, J., Lennert, K., Ehn, J. K., Boone, W., Galindo, V., Hu, Y., Dmitrenko, I. A., Kirillov, S. A., Kjeldsen, K. K., Kristoffersen, Y., Barber, D. G., and Rysgaard, S.: Sea ice breakup and marine melt of a retreating tidewater outlet glacier in northeast Greenland $\left(81^{\circ} \mathrm{N}\right)$, Sci. Rep., 7, 4941, https://doi.org/10.1038/s41598-017-05089-3, 2007.

Bignami, F. and Hopkins, T. S.: The water mass characteristics of the Northeast Water Polynya: Polar Sea data 1992-1993, J. Mar. Syst., 10, 139-156, 1997.

Budéus, G., Schneider, W., and Kattner, G.: Distribution and exchange of water masses in the Northeast Water polynya (Greenland Sea), J. Mar. Syst., 10, 139-156, 1997.

de Steur, L., Hansen, E., Gerdes, R., Karcher, M., Fahrbach, E., and Holfort, J.: Freshwater fluxes in the East Greenland Current: A decade of observations, Geophys. Res. Lett., 36, L23611, https://doi.org/10.1029/2009GL041278, 2009.

Dmitrenko, I. A., Kirillov, S. A., Krumpen, T., Makhotin, M., Abrahamsen, E. P., Willmes, S., Bloshkinab, E., Hölemann, J. A., Kassens, H., and Wegner, C.: Wind-driven diversion of summer river runoff preconditions the Laptev Sea coastal polynya hydrography: Evidence from summer-to-winter hydrographic records of 2007-2009, Cont. Shelf Res., 30, 1656-1664, https://doi.org/10.1016/j.csr.2010.06.012, 2010.

Dmitrenko, I. A., Ivanov, V. V., Kirillov, S. A., Vinogradova, E. L., Torres-Valdes, S., and Bauch, D.: Properties of the Atlantic derived halocline waters over the Laptev Sea continental margin: Evidence from 2002 to 2009, J. Geophys. Res., 116, C10024, https://doi.org/10.1029/2011JC007269, 2011. 
Dmitrenko, I. A., Kirillov, S. A., Bloshkina, E., and Lenn, Y.-D.: Tide-induced vertical mixing in the Laptev Sea coastal polynya, J. Geophys. Res., 117, C00G14, https://doi.org/10.1029/2011JC006966, 2012.

Dmitrenko, I. A., Kirillov, S. A., Forest, A., Gratton, Y., Volkov, D. L., Williams, W. J., Lukovich, J. V., Belanger, C., and Barber, D. G.: Shelfbreak current over the Canadian Beaufort Sea continental slope: Wind-driven events in January 2005, J. Geophys. Res.-Oceans, 121, 2447-2468, https://doi.org/10.1002/2015JC011514, 2016.

Eicken, H.: Structure of under-ice melt ponds in the central Arctic and their effect on the sea-ice cover, Limnol. Oceanogr., 39, 682694, 1994.

Falck, E.: Contribution of waters of Atlantic and Pacific origin in the Northeast Water Polynya, Polar Res., 20, 193-200, 2001.

Falck, E., Kattner, G., and Budéus, G.: Disappearance of Pacific Water in the northwestern Fram Strait, Geophys. Res. Lett., 32, L14619, https://doi.org/10.1029/2005GL023400, 2005.

Flocco, D., Feltham, D. L., Bailey, E., and Schroeder, D.: The refreezing of melt ponds on Arctic sea ice, J. Geophys. Res., 120, 647-659, https://doi.org/10.1002/2014JC010140, 2015.

Granskog, M. A., Stedmon, C. A., Dodd, P. A., Amon, R. M. W., Pavlov, A. K., de Steur, L., and Hansen, E.: Characteristics of colored dissolved organic matter (CDOM) in the Arctic outflow in the Fram Strait: Assessing the changes and fate of terrigenous CDOM in the Arctic Ocean, J. Geophys. Res., 117, C12021, https://doi.org/10.1029/2012JC008075, 2012.

Guéguen, C., Guo, L., Yamamoto-Kawai, M., and Tanaka, N.: Colored dissolved organic matter dynamics across the shelf-basin interface in the western Arctic Ocean, J. Geophys. Res., 112, C05038, https://doi.org/10.1029/2006JC003584, 2007.

$\mathrm{Hu}, \mathrm{X}$. and Myers, P. G.: A Lagrangian view of $\mathrm{Pa}-$ cific water inflow pathways in the Arctic Ocean during model spin-up, Ocean Model., 71, 66-80, https://doi.org/10.1016/j.ocemod.2013.06.007, 2013.

Inall, M. E., Murray, T., Cottier, F. R., Scharrer, K., Boyd, T. J., Heywood, K. J., and Bevan, S. L.: Oceanic heat delivery via Kangerdlugssuaq Fjord to the south-east Greenland ice sheet, J. Geophys. Res., 119, 631-645, https://doi.org/10.1002/2013JC009295, 2014.

Jeansson, E., Jutterström, S., Rudels, B., Anderson, L. G., Olsson, K. A., Jones, E. P., Smethie Jr., W. M., and Swift, J. H.: Sources to the East Greenland Current and its contribution to the Denmark Strait Overflow, Prog. Oceanogr., 78, 12-28, https://doi.org/10.1016/j.pocean.2007.08.031, 2008.

Jenkins, A.: The impact of melting ice on ocean waters, J. Phys. Oceanogr., 29, 2370-2381, 1999.

Jones, E. P.: Circulation in the Arctic Ocean, Polar Res., 20, 139146, https://doi.org/10.3402/polar.v20i2.6510, 2001.

Jones, E. P. and Anderson, L. G.: On the origin of the chemical properties of the Arctic Ocean halocline, J. Geophys. Res., 91, 10759-10767, https://doi.org/10.1029/JC091iC09p10759, 1986.

Jones, E. P., Anderson, L. G., and Swift, J. H.: Distribution of Atlantic and Pacific waters in the upper Arctic Ocean: Implications for circulation, Geophys. Res. Lett., 25, 765-768, 1998.

Jones, E. P., Swift, J. H., Anderson, L. G., Lipizer, M., Civitarese, G., Falkner, K. K., Kattner, G., and McLaughlin, F. A.: Tracing Pacific water in the North Atlantic Ocean, J. Geophys. Res., 108, 3116, https://doi.org/10.1029/2001JC001141, 2003.
Jones, E. P., Anderson, L. G., Jutterström, S., and Swift, J. H.: Sources and distribution of fresh water in the East Greenland Current, Prog. Oceanogr., 78, 37-44, https://doi.org/10.1016/j.pocean.2007.06.003, 2008.

Kattner, G.: The Expedition of the Research Vessel "Polarstern" to the Arctic in 2008 (ARK-XXIII/2), Ber. Polarforsch., 590, 88, 2009.

Kirillov, S., Dmitrenko, I., Rysgaard, S., Babb, D., Pedersen, L. T., Ehn, J., Bendtsen, J., and Barber, D.: Storm-induced water dynamics and thermohaline structure at the tidewater Flade Isblink Glacier outlet to the Wandel Sea (NE Greenland), Ocean Sci., 13, 947-959, https://doi.org/10.5194/os-13-947-2017, 2017.

Mayer, C., Reeh, N., Jung-Rothenhausler, F., Huybrechts, P., and Oerter, H.: The subglacial cavity and implied dynamics under Nioghalvfjerdsfjorden Glacier, NE-Greenland, Geophys. Res. Lett., 27, 2289-2292, 2000.

McLaughlin, F. A., Carmack, E. C., MacDonald, R. W., Melling, H., Swift, J. H., Wheeler, P. A., Sherr, B. F., and Sherr, E. B.: The joint roles of Pacific and Atlantic-origin waters in the Canada Basin, 1997-1998, Deep-Sea Res. Pt. I, 51, 107-128, 2004.

Nørgaard-Pedersen, N., Mikkelsen, N., and Kristoffersen, Y.: Late glacial and Holocene marine records from the Independence Fjord and Wandel Sea regions, North Greenland, Polar Res., 27, 209-221, https://doi.org/10.1111/j.1751-8369.2008.00065.x, 2008.

Palmer, S. J., Shepherd, A., Sundal, A., Rinne, E., and Nienow, P.: InSAR observations of ice elevation and velocity fluctuations at the Flade Isblink ice cap, eastern North Greenland, J. Geophys. Res., 115, F04037, https://doi.org/10.1029/2010JF001686, 2010.

Pickart, R. S., Weingartner, T. J., Pratt, L. J., Zimmermann, S., and Torres, D. J.: Flow of winter-transformed Pacific water into the western Arctic, Deep-Sea Res. Pt. II, 52, 3175-3198, 2005.

Polyakov, I. V., Timokhov, L. A., Alexeev, V. A., Bacon, S., Dmitrenko, I. A., Fortier, L., Frolov, I. E., Gascard, J.-C., Hansen, E., Ivanov, V. V., Laxon, S., Mauritzen, C., Perovich, D., Shimada, K., Simmons, H. L., Sokolov, V. T., Steele, M., and Toole, J.: Arctic Ocean warming contributes to reduced polar ice cap, J. Phys. Oceanogr., 40, 2743-2756, https://doi.org/10.1175/2010JPO4339.1, 2010.

Rinne, E. J., Shepherd, A., Palmer, S., van den Broeke, M. R., Muir, A., Ettema, J., and Wingham, D.: On the recent elevation changes at the Flade Isblink Ice Cap, northern Greenland, J. Geophys. Res., 116, F03024, https://doi.org/10.1029/2011JF001972, 2011.

Rudels, B.: Arctic Ocean circulation and variability - advection and external forcing encounter constraints and local processes, Ocean Sci., 8, 261-286, https://doi.org/10.5194/os-8-261-2012, 2012.

Rudels, B., Jones, E. P., Anderson, L. G., and Kattner, G.: On the intermediate depth waters of the Arctic Ocean, in: The Polar Oceans and Their Role in Shaping the Global Environment: The Nansen Centennial Volume, Geophys. Monogr. Ser., vol. 84985, edited by: Johannessen, O. M., Muench, R. D., and Overland, J. E., AGU, Washington, D.C., 33-46, 1994.

Rudels, B., Anderson, L. G., and Jones, E. P.: Formation and evolution of the surface mixed layer and halocline of the Arctic Ocean, J. Geophys. Res., 101, 8807-8821, https://doi.org/10.1029/96JC00143, 1996.

Rudels, B., Fahrbach, E., Meincke, J., Budéus, G., and Eriksson, P.: The East Greenland Current and its contribution to the 
Denmark Strait overflow, ICES J. Mar. Sci., 59, 1133-1154, https://doi.org/10.1006/jmsc.2002.1284, 2002.

Rudels, B., Jones, E. P., Schauer, U., and Erikssondels, P.: Atlantic sources of the Arctic Ocean surface and halocline waters, Polar Res., 23, 181-208, 2004.

Rudels, B., Björk, G., Nilsson, J., Winsor, P., Lake, I., and Nohr, C.: The interaction between waters from the Arctic Ocean and the Nordic Seas north of Fram Strait and along the East Greenland Current: results from the Arctic Ocean-02 Oden expedition, J. Mar. Syst., 55, 1-30, https://doi.org/10.1016/j.jmarsys.2004.06.008, 2005.

Shimada, K., Itoh, M., Nishino, S., McLaughlin, F., Carmack, E., and Proshutinsky, A.: Halocline structure in the Canada Basin of the Arctic Ocean, Geophys. Res. Lett., 32, L03605, https://doi.org/10.1029/2004GL021358, 2005.

Steele, M., Morison, J., Ermold, W., Rigor, I., Ortmeyer, M., and Shimada, K.: Circulation of summer Pacific halocline water in the Arctic Ocean, J. Geophys. Res., 109, C02027, https://doi.org/10.1029/2003JC002009, 2004.

Stevens, L. A., Straneo, F., Das, S. B., Plueddemann, A. J., Kukulya, A. L., and Morlighem, M.: Linking glacially modified waters to catchment-scale subglacial discharge using autonomous underwater vehicle observations, The Cryosphere, 10, 417-432, https://doi.org/10.5194/tc-10-417-2016, 2016.

Straneo, F., Curry, R. G., Sutherland, D. A., Hamilton, G. S., Cenedese, C., Våge, K., and Stearns, L. A.: Impact of fjord dynamics and glacial runoff on the circulation near Helheim Glacier, Nat. Geosci., 4, 322-327, https://doi.org/10.1038/ngeo1109, 2011.

Straneo, F., Sutherland, D., Holland, D., Gladish, C., Hamilton, G. S., Johnson, H. L., Ringot, E. R., Xu, Y., and Koppes, M.: Characteristics of ocean waters reaching Greenland's glaciers, Ann. Glaciol., 53, 202-210, https://doi.org/10.3189/2012AoG60A059, 2012.

Sutherland, D. A. and Pickart, R. S.: The East Greenland Coastal Current: Structure, variability, and forcing, Prog. Oceanogr., 78, 58-77, https://doi.org/10.1016/j.pocean.2007.09.006, 2008.
Sutherland, D. A. and Straneo, F.: Estimating ocean heat transports and submarine melt rates in Sermilik Fjord, Greenland, using lowered acoustic Doppler current profiler (LADCP) velocity profiles, Ann. Glaciol., 53, 50-58, https://doi.org/10.3189/2012AoG60A050, 2012.

Sutherland, D. A., Pickart, R. S., Peter Jones, E., AzetsuScott, K., Jane Eert, A., and Oillafsson, J.: Freshwater composition of the waters off southeast Greenland and their link to the Arctic Ocean, J. Geophys. Res., 114, C05020, https://doi.org/10.1029/2008JC004808, 2009.

von Appen, W.-J. and Pickart, R. S.: Two Configurations of the Western Arctic Shelfbreak Current in Summer, J. Phys. Oceanogr., 42, 329-351, https://doi.org/10.1175/JPO-D11-026.1, 2012.

Walsh, D. and Carmack, E.: The nested structure of Arctic thermohaline intrusions, Ocean Model., 5, 267-289, https://doi.org/10.1016/S1463-5003(02)00056-2, 2003.

Weingartner, T., Cavalieri, D., Aagaard, K., and Sasaki, Y.: Circulation, dense water formation, and outflow on the northeast Chukchi shelf, J. Geophys. Res., 103, 7647-7661, 1998.

Wexler, H.: Heating and melting of floating ice shelves, J. Glaciol., 3, 626-645, 1960.

Wilson, N. J. and Straneo, F.: Water exchange between the continental shelf and the cavity beneath Nioghalvfjerdsbræ (79 North Glacier), Geophys. Res. Lett., 42, 7648-7654, https://doi.org/10.1002/2015GL064944, 2015.

Woodgate, R.: Arctic Ocean Circulation: Going Around At the Top Of the World, Nat. Educ. Knowledge, 4, 8, 2013.

Woodgate, R. A., Aagaard, K., and Weingartner, T. J.: A year in the physical oceanography of the Chukchi Sea: Moored measurements from autumn 1990-1991, Deep-Sea Res. Pt. II, 52, 3116-3149, https://doi.org/10.1016/j.dsr2.2005.10.016, 2005.

Woodgate, R. A., Aagaard, K., Swift, J. H., Smethie Jr., W. M., and Falkner, K. K.: Atlantic water circulation over the Mendeleev Ridge and Chukchi Borderland from thermohaline intrusions and water mass properties, J. Geophys. Res., 112, C02005, https://doi.org/10.1029/2005JC003416, 2007. 